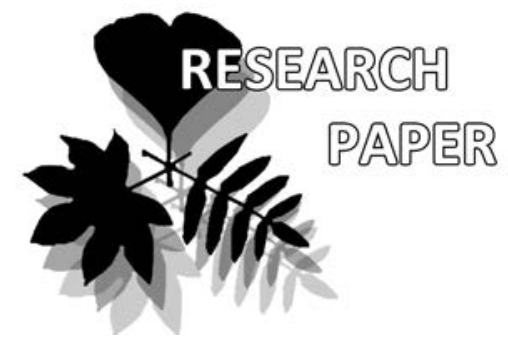

\title{
The first record of catastrophic windthrow in boreal forests of South Sakhalin and the South Kurils (Russia) during October 2015 tropical cyclones
}

\author{
Kirill A. Korznikov ${ }^{1 *}$, Dmitriy E. Kislov ${ }^{1} \&$ Nadezhda G. Belyaeva $^{2}$
}

Kirill A. Korznikov ${ }^{1 *}$

e-mail: korzkir@mail.ru

Dmitriy E. Kislov ${ }^{1}$

e-mail: kislov@easydan.com

Nadezhda G. Belyaeva ${ }^{3}$

e-mail: nadejda.beliaeva2012@yandex.ru

${ }^{1}$ Botanical Garden-Institute FEB RAS,
Vladivostok, Russia
${ }^{2}$ Institute of Geography RAS, Moscow,
Russia

* corresponding author

Manuscript received: 01.03.2018

Review completed: 25.04.2019

Accepted for publication: 30.04.2019

Published online: 02.05.2019

\begin{abstract}
A B S T R A C T
Tropical cyclones that swept across South Sakhalin and the southern part of the Kuril Islands in early October of 2015 produced strong winds and heavy precipitation. They resulted in large-scale windthrow patches in zonal dark-conifer forests dominated of Abies sachalinensis and Picea jezoensis, as well as secondary forests of various composition. We identified the distribution of these windthrows, estimated their area, and assessed the total wood biomass loss. Forest change area and wood biomass data by Global Forest Watch project was used for the analysis. Through comparison examination of these data with satellite images of very-high resolution we established that windthrows located on Sakhalin Island are recognized with high accuracy, while their area on the Kuril Islands is presented significantly lower than the area of actual damages. We recommend using methods of higher precision level for future windthrow identifications on the Kuril Islands. The total area of windthrows on Sakhalin was calculated at $425.98 \mathrm{~km}^{2}$ with the wood mortality of $4.72 \cdot 10^{6}$ tons. We found no significant correlation between windthrow patch distribution and local topographic conditions such as elevation above sea level and slope gradient. At the same time, forests growing on slopes with western exposure on Sakhalin Island revealed greater damage which is correlated with the wind direction during the disturbance events.
\end{abstract}

K e y w o r d s : windthrow, forest disturbance, forest loss, tropical cyclone, typhoon

\section{P E 3 Ю M E}

Корзников К.А., Кислов А.Е., Беляева Н.Г. Массовые ветровалы в темнохвойных бореальных месах юга Сахалина и Южных Курим вслеАствие прохожАения тропических цикмонов в октябре 2015 года. Тропические циклоны, прошедшие нал южной частью Сахалина и южными Курильскими островами в начале октября 2015 года, вызвали сильные ветра и обильные осадки. Результатом их воздействия стало появление масштабных ветровалов в зональных темнохвойных месах из Abies sachalinensis и Picea jezoensis, а также вторичных месах различного состава. Мы определили размещение ветровальных участков, оценили их площадь и общие потери Аревесины. Аля этого использовали данные Global Forest Watch о сокрашении месной площади и биомассе Аревесины. Сравнив эти данные с изображениями космических снимков сверхвысокого разрешения установили, что ветровацьные участки на Сахалине распознаются достаточно точно, а на Курильских островах их площадь существенно ниже реальной. Аля илентификации ветровалов на Курилах следует использовать более утонченные методы. Общая площадь ветровалов на Сахалине составила 425.98 км² $^{2}$ а масса погибшей Аревесины $-4.72 \cdot 10^{6}$ тонн. Мы не обнаружили явно выраженной зависимости межАу распределением ветровалов и топографическими условиями - высотой наА уровнем моря и крутизной склонов. В то же время на Сахалине сильнее оказались нарушены меса скцонов западной экспозиции, что связано с преобладающим направлением ураганных ветров.

Ключевые слова: ветровал, нарушение леса, потеря ^еса, тропический циклон, тайфун
Strong wind is one of the main causes of natural disturbances in forest ecosystems (Everham \& Brokaw 1996, McCarthy 2001, Mitchell 2013, Turton \& Alamgir 2015). In tropical and temperate forested regions characterized by monsoonal climate, regular wind disturbance events are triggered by tropical cyclones that are commonly termed hurricanes in America and typhoons in Asia (Boose et al. 1994, Fischer et al. 2013, Xi 2015). Frequent wind damage is the main factor of natural dynamics of the East Asian tropical and temperate forests located in China, Japan and on the Korean Peninsula (Ishizuka et al. 1994, Nakashizuka \& Iida 1996, Xue et al. 2009, Guo et al. 2010, Jang \& Park 2010, Nakajima et al. 2009, Yoshida et al. 2011, Itô et al. 2018). Large scale wind disturbances in boreal forests are fairly rare and their consequences are less studied than those in tropical and temperate forests. At the same time, their 
role in forest dynamics and ecosystem development is of high importance (Ulanova 2000, Angelstam \& Kuuluvainen 2004, Rich et al. 2007).

At high latitudes, tropical cyclones are transformed into extratropical cyclones characterized by the decrease of wind speed and precipitation amount (Hart \& Evans 2001). Large-scale disturbance events are rare in boreal forests of the insular sector of the Russian Far East (Sakhalin and the Kuril Islands). There are data, however, pointing to medium-scale forest disturbances on Sakhalin caused by strong winds (Tsymek \& Solov'yev 1948; unpublished manuscript about vegetation of South Sakhalin (1958) by V.D. Lopatin).

In early October of 2015, South Sakhalin and the South Kuril Islands (Kunashir, Iturup, and Shikotan) suffered two catastrophic cyclones: Ex-Typhoon Dujuan and Typhoon Chi-Wan. These extreme wind events led to the appearance of large windthrow patches in southern boreal dark conifer forests with Jezo spruce (Picea jezoensis (Siebold \& Zucc.) Carrière) and Sakhalin fir (Abies sachalinensis (F. Schmidt) Mast.).

In this paper, we provide the first documented windthrow area estimates for the October 2015 events, as well as the spatial and topographic distribution analysis of the windthrows based on the remote sensing data. We also provide an estimate of the wood mortality associated with the typhoons.

\section{MATERIAL AND METHODS}

\section{Natural environment and forest vegetation in the region}

Sakhalin and the Kuril Islands climate is monsoonal, also known as humid continental climate with warm summer (Dfb) as per Köppen classification (Peel et al. 2007). Average annual temperature in the southern part of Sakhalin is $2.8^{\circ} \mathrm{C}$, annual precipitation is $864 \mathrm{~mm}$ (at YuzhnoSakhalinsk). Average annual temperature on Kunashir Island is $5.1^{\circ} \mathrm{C}$, annual precipitation is $1253 \mathrm{~mm}$ (at Yuzhno-Kurilsk). With prevailing low-mountain relief, the maximum elevation on South Sakhalin is $1054 \mathrm{~m}$ (Peak Chekhova), on Kunashir Island - 1819 m (Tyatya volcano), and on Iturup Island - $1634 \mathrm{~m}$ (Stokap volcano). The prevailing soil type is Podzols (Ivlev 1965).

The insular sector of the Russian Far East's zonal vegetation is represented by dark conifer forests with Picea jezoensis and Abies sachalinensis dominance. In southwestern Sakhalin, as well as the southern part of the Kuril Islands, forest stands include Acer mayrii Schwer., Kalopanax septemlobus Thunb., and Phellodendron sachalinense (F. Schmidt) Sarg. In lowlands and bogs, Larix cajanderi Mayr stands are present. On Kunashir and Iturup Islands, as well as Southeast Sakhalin, forests are dominated by Picea glehnii (F. Schmidt) Mast. There are stands of Quercus mongolica Fisch. ex Ledeb. (incl. Quercus mongolica subsp. crispula (Blume) Menitsky) in the southern parts of Kunashir, as well as central Iturup, while on Sakhalin Island, oak forests are extremely rare. The upper mountain timber zone in the region is comprised of Betula ermanii Cham., above which thickets of Pinus pumila (Pall.) Regel are found. Betula ermanii and Betula platyphylla Sukaczev are found as fillers in dark conifer forests and secondary stands regenerated after logging and fires.

\section{Weather conditions during the disturbance events}

According to the meteorological data (daily weather archive, https://rp5.ru/) recorded at Mys' Krilion (Cape Krilion) weather station, wind gusts speeds reached the record high of $60 \mathrm{~m} \cdot \mathrm{s}^{-1}$ during the typhoons' passage. On the western shores of Sakhalin Island, gusts speeds of up to $45 \mathrm{~m} \cdot \mathrm{s}^{-1}$ were registered. Strong winds were accompanied by heavy precipitation (Table 1). Wind gusts and the cumulative precipitation amounts might have been higher in the mountain valleys, although this is not supported by measuring instruments.

\section{Windthrow patches identification}

To identify windthrows we utilized the 2016-2017 data on forest cover loss with the canopy closure of $>25 \%$ and the spatial image resolution of $30 \times 30 \mathrm{~m}$ (Hansen et al. 2013). The need for tracking forest mortality not only a year but also two years after a windstorms events is explained on the grounds of delayed mortality of damaged trees, as well as the time it takes for fallen trees to defoliate fully. Further on, by superimposing satellite images of high and very-high resolution, we were able to exclude from analysis the sites that match the anthropogenic forest disturbances such as logging, as well as the sites of forest mortality from natural causes such as fires, insects, and flooding. We also conducted ground assessments of species composition of the damaged stands at 15 sites on South Sakhalin to determine the wind vulnerability of their forest types (Table 2).

Data processing was performed in Python programming language using various libraries for scientific computing (Oliphant 2007) such as SciPy (http://scipy.org), NumPy (http://numpy.org) and Gdal (http://gdal.org). The latter was used to read source data obtained from topographic

Table 1. Meteorological conditions during windstorm events

\begin{tabular}{|c|c|c|c|}
\hline Location & $\begin{array}{l}\text { 10-minutes max mean wind } \\
\text { speed, } \mathrm{m} \cdot \mathrm{s}^{-1}\end{array}$ & Maximum wind speed, $\mathrm{m} \cdot \mathrm{s}^{-1}$ & Precipitations by $12 \mathrm{~h}, \mathrm{~mm}$ \\
\hline \multicolumn{4}{|c|}{ Ex-Dujuan typhoon, 02.10.2015 } \\
\hline Kholmsk & 15 & 45 & 17 \\
\hline Tomari & 23 & 36 & 21 \\
\hline Yuzhno-Sakhalinsk & 16 & 31 & 29 \\
\hline Yuzhno-Kurilsk & 17 & 31 & 13 \\
\hline \multicolumn{4}{|c|}{ Choi-Wan typhoon, 09.10.2015 } \\
\hline Kholmsk & 7 & 22 & 11 \\
\hline Tomari & 9 & 20 & 13 \\
\hline Yuzhno-Sakhalinsk & 10 & 30 & 41 \\
\hline Yuzhno-Kurilsk & 12 & 27 & 10 \\
\hline
\end{tabular}


Table 2. List of fieldwork locations with disturbed forest types

\begin{tabular}{lll}
\hline No & Location & Disturbed forest types \\
\hline 1 & Puzina Peninsula, unnamed hills & dark conifer \\
2 & Korsakovskoe Platae & secondary birch, larch plantation \\
3 & Korsakovskoe Platae & secondary larch, larch plantation \\
4 & Susunayskiy Range, W macroslope, Markovka River valley & dark conifer \\
5 & Susunayskiy Range, E macroslope, Ochepukha River valley & dark conifer \\
6 & Susunayskiy Range, W macroslope, Rogatka River valley & dark conifer, dark conifer plantation, secondary birch \\
7 & Susunayskiy Range, E macroslope, Zhukovka River valley & dark conifer \\
8 & Susunayskiy Range, E macroslope, Anna River valley & dark conifer, secondary birch \\
9 & Yuzhno-Kamischeviy Range, Poyasok Isthmus & dark conifer, larch plantation \\
10 & Yuzhno-Kamischeviy Range, E macroslope, Nayba River valley & dark conifer \\
11 & Yuzhno-Kamischeviy Range, W macroslope, Kostroma River valley & dark conifer, secondary birch \\
12 & Mitsulskiy Range, E macroslope, & dark conifer, pine plantation \\
13 & Yuzhno-Kamischeviy Range, E macroslope, Bryanka River valley & dark conifer \\
14 & Yuzhno-Kamischeviy Range, watershed & dark conifer \\
15 & Yuzhno-Kamischeviy Range, W macroslope & dark conifer \\
\hline
\end{tabular}

and forest dynamics databases. Basic data processing and evaluation steps included the following:

1. Data reading from source files. We loaded and processed numerous geoTIFF layers that included forest loss intensity (Hansen et al. 2013), topographic data (including elevation ASL, slopes, and aspects) (NASA... 2013), and wood biomass productivity (aboveground live woody biomass density $30 \mathrm{~m}$ resolution layer by Global Forest Watch, https:// www.globalforestwatch.org).

2. Computing basic characteristics of windthrow patches, including cumulative area of affected forest cover and their relationship to the local topographic conditions.

3. Comparison analysis of distribution homogeneity of the selected characteristics for the disturbed sites and the entire forested territories using Kolmogoroff-Smirnoff test.

4. Patch connectivity analysis. This step was aimed at investigating wind damage specificity and focused on finding size distribution of windthrow patches. We defined a patch as a set of elementary cells (of size $30 \times 30 \mathrm{~m}$ ) that are spatially connected with each other (including diagonal neighborhood). To identify all connected cells, we used labeling algorithm from the Scikit-image package (van der Walt et al. 2014).

\section{RESULTS}

Verification of windthrow patches using high-resolution satellite images showed close correspondence to the contours of the damaged sites in Sakhalin and a significant underestimation of the affected area on the Kuril Islands (Fig. 1). For this reason, the data shown below should be treated as near accurate for Sakhalin and lower than accurate and requiring better refined identification methods for the Kuril Islands (Fig. 2).

The total area of the windthrow patches on Sakhalin Island south of $48.5^{\circ} \mathrm{N}$ equals $425.98 \mathrm{~km}^{2}$ which is about $3.38 \%$ of the entire forest. On Kunashir Island, the windthrow patches total area amounts to $11.30 \mathrm{~km}^{2}(0.92 \%)$, on southern part of Iturup Island $-9.57 \mathrm{~km}^{2}(0.97 \%)$, and on Shikotan Island $-0.73 \mathrm{~km}^{2}(0.71 \%)$. Above given windthrow areas when accounted for the topographic curvature add up to $447.13 \mathrm{~km}^{2}$ on Sakhalin, $11.56 \mathrm{~km}^{2}$ on Kunashir, $9.61 \mathrm{~km}^{2}$ on Iturup, and $0.76 \mathrm{~km}^{2}$ on Shikotan Island.

The total loss of wood biomass on Sakhalin equals $4.72 \cdot 10^{6}$ tons $\left(110.81 \pm 13.35 \mathrm{t} \cdot \mathrm{ha}^{-1}\right.$; mean \pm SD), on Kunashir
$-0.17 \cdot 10^{6}$ tons $\left(146.84 \pm 9.07 \mathrm{t} \cdot \mathrm{ha}^{-1}\right)$, on Iturup $-0.14 \cdot 10^{6}$ tons $\left(143.62 \pm 7.70 \mathrm{t} \cdot \mathrm{ha}^{-1}\right)$, and on Shikotan $-<0.01 \cdot 10^{6}$ tons $\left(123.09 \pm 36.93 \mathrm{t} \cdot \mathrm{ha}^{-1}\right)$.

On Kunashir and Iturup, windthrow patches are associated with the lower sections of mountains and hills with the slope gradient of $<10^{\circ}$. On Sakhalin, largest windthrow patches by area are found on mountainsides with the gradient of $10-20^{\circ}$ and at 200 to $400 \mathrm{~m}$. in elevation. Most of the windthrow total area on Sakhalin is associated with west-facing exposure $\left(180-360^{\circ}\right)$, while it is south-east and south-facing on Kunashir $\left(50-200^{\circ}\right)$. As for Iturup Island, most of its disturbed sites are located on non-sloping surfaces, therefore lacking the exposure-related windthrow distinction (Fig. 3).

The main disturbed sites in South Sakhalin are located on the Sea of Japan coast in river valleys of the western Yuzhno-Kamishoviy Range macroslope (the term defines part of a large mountain system with a certain aspect) where the historic wind speeds were recorded during the October 2, 2015 typhoon. On Kunashir Island, most of the windthrow patches are located in the island center, as well as the slopes of Tyatya volcano. On Iturup, windthrow events are recorded on the eastern slopes of Atsonopuri volcano and the valley floor between Atsonopuri and Stokap volcano.

A significant proportion of the total disturbed area accrues to the windthrow patches less than $0.25 \mathrm{~km}^{2}$ in size (Fig. 4). There are also sites of large-scale windthrows with the area of up to $14 \mathrm{~km}^{2}$ recorded on West Sakhalin coastal line, although their ratio of the total disturbance area is not large. No windthrow patches larger than $0.4 \mathrm{~km}^{2}$ were identified on Kunashir Island, which could be due to poor definition of wind disturbed patches.

\section{DISCUSSION}

As revealed by the verification analysis, usage of global forest dynamics data (Hansen et al. 2013) for the purpose of identification of the forest sites damaged by windstorms was applicable to Sakhalin Island and provided underestimated results for the Kuril Islands. This is likely related to both the poor quality of satellite images due to the maritime climate dense cloud cover and frequent fog events, 

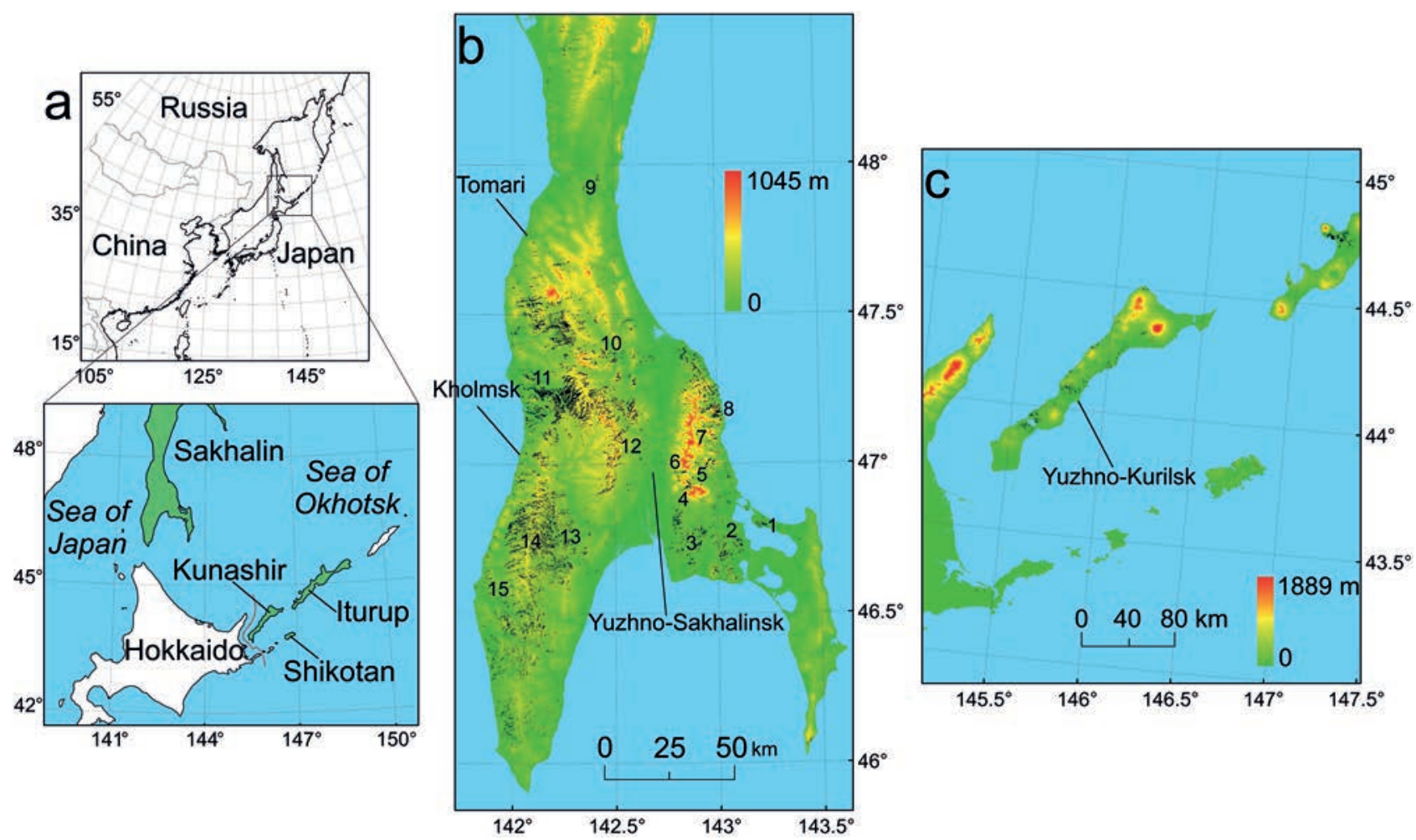

Figure 1 Study region (a) and windthrows distribution after the October 2015 disturbance events (b). Numbers on relief map of Sakhalin Island indicate fieldwork locations (Table 2). Windthrow patches are colored in black on relief maps, all disturbed patches marked in real scale

and the specific composition of the regional vegetation such as the presence of thick dwarf bamboo growths under the overstory canopy (Sasa spp.). Therefore, a more precise forest disturbance sites identification for the Kuril Islands requires different methods of remote sensing, for example satellite images of high and very-high resolution (Einzmann et al. 2017) and data collection by unmanned aerial vehicles (Getzin et al. 2014, Mokroš et al. 2017).

The overall area of the disturbed forests on Sakhalin $\left(425.98 \mathrm{~km}^{2}\right)$ is consistent with similar typhoon-related

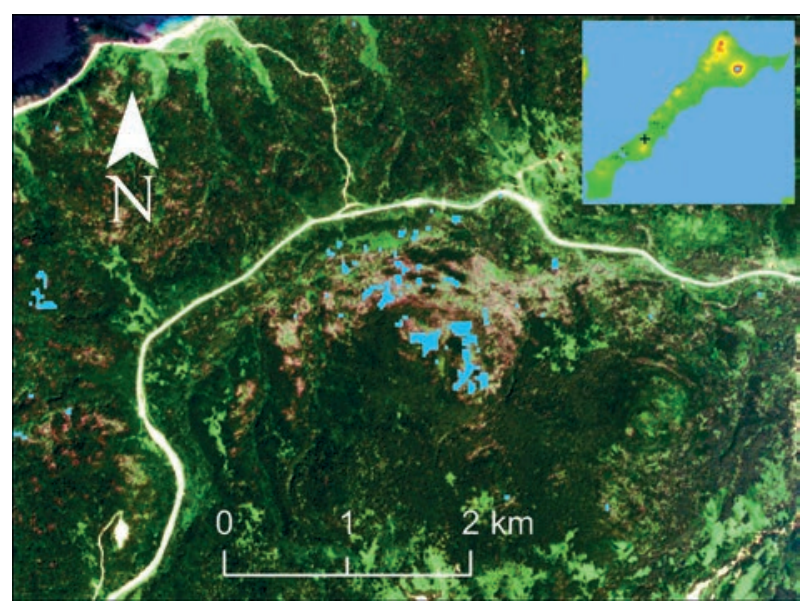

Figure 2 Comparison of real windthrow patches (grey colors) using high-resolution satellite image and patches interpreted as forest loss (blue color) on Kunashir Island (by Sentinel-2, 14.07.2017) forest damage in Japan (Morimoto et al. 2011). However, while in Japan disturbance events of such magnitude are a relatively frequent phenomenon, they were recorded for the first time in history on Sakhalin Island. To put this into perspective, over the 2000-2015 time period, the South Sakhalin total forest loss area including both natural mortality due to fires, insects, snow slides and anthropogenic causes such as logging and construction site clearance adds up to only $75 \mathrm{~km}^{2}$.

We attribute the cause of such severe wind blowdown to the record wind speeds accompanied by heavy precipitation. There is significant research discussing the reasons behind forest vulnerability to wind damage. Besides wind speed, other contributing factors include topography (Kramer et al. 2001, Kulakowski \& Veblen 2002, Seidl et al. 2011), forest composition including prior damage with logging among others (Mitchell et al. 2001, Rich et al. 2007, Taylor et al. 2019), and stand type: natural growth or plantation (Morimoto et al. 2019).

Although we have data on the topography of the damaged sites, it does not support a strict adherence of the windthrows' locations to any specific topographic condition. The largest portion of windthrow sites on Sakhalin is set on range slopes facing the Sea of Japan (Yuzhno-Kamishoviy Range) and the Okhotsk Sea (Susunaiskiy Range). We are attributing such distribution to strong west winds of October 2, 2015, as well as the extreme south-east wind conditions of October 9. Thus, the local wind speeds and its direction become the more significant factors leading to the observed damage. 

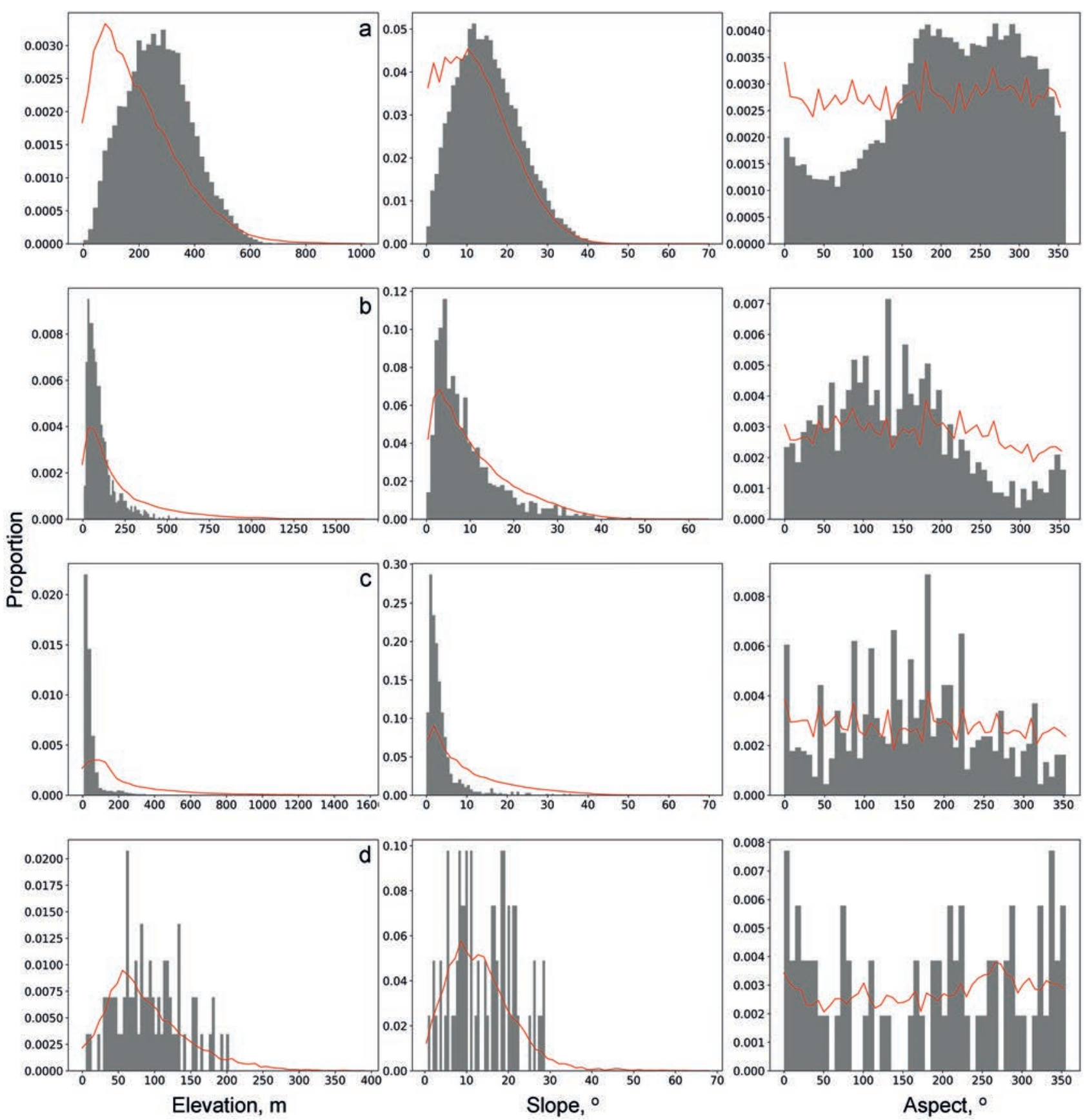

Figure 3 Probability density function estimations of windthrow area by slope gradient, elevation, and by aspect with total forested area (red curve) for comparison. Line a - Sakhalin, b-Kunashir, c - Iturup, d - Shikotan

Nonetheless, various forest types growing in different topographic conditions would differ in their wind resistance characteristics. For example, dwarf stands of Pinus pumila and Betula ermanii krummholz are highly resistant to wind damage and grow on steep upper mountain zones and watershed dividing ridges. Wind damage has not been noted for such forests. Lower sloping sections is where the dark conifer and mixed fir, spruce and birch forests are located and suffered the most significant disturbances.

Insufficient knowledge about the spatial plant distribution and the lack of digital data on Sakhalin and the Kuril Islands' vegetation prevent our ability to perform a quantitative evaluation of the windthrow area for different fo- rest types. According to field observation data taken at 15 windthrow sites, damage to dark conifer forest stands located next to undisturbed mixed and broadleaf-dark conifer forests is universally noted. Secondary birch forest damage is found at 5 sites only (Table 2). There are massive windthrows found in forests comprised of Larix cajanderi in south-eastern parts of Sakhalin (Korsakovskoe Plateau) where this species is dominant (Tolmachev 1955, Krestov et al. 2004). Based on this information, we come to a preliminary conclusion that dark conifer forests were affected by windthrow events more than secondary mixed and birch forests.

The newly formed windthrow sites will lead to significant changes in species composition, spatial structure, and forest 


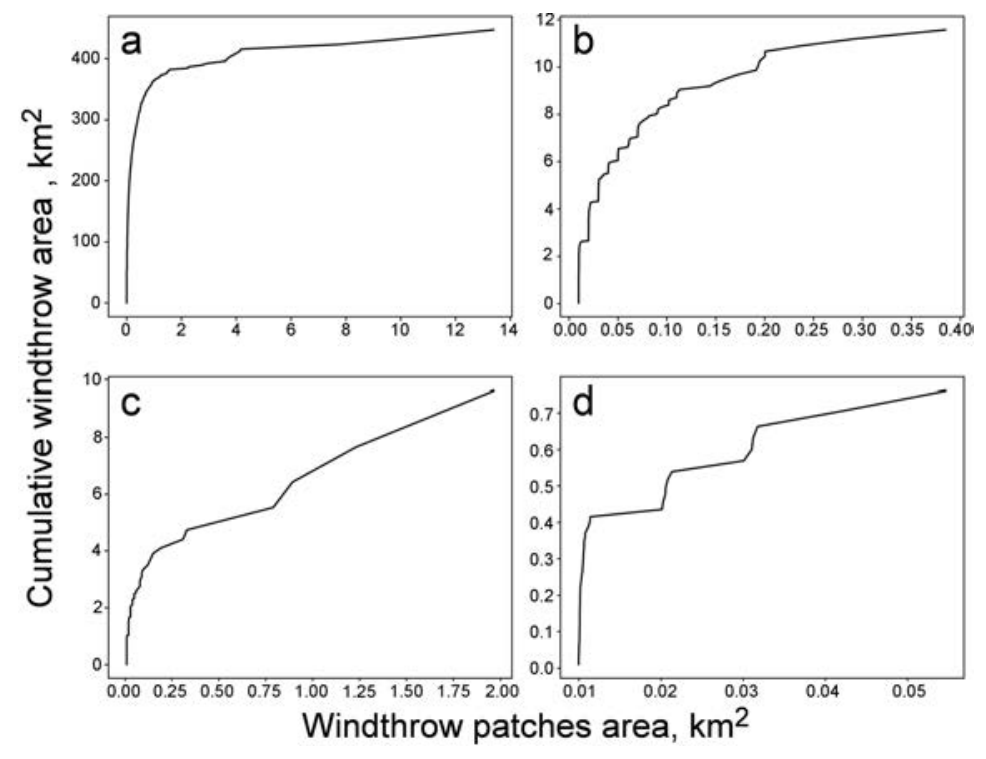

Figure 4 Cumulative area of windthrows in relation to the size of individual disturbed patches; a - Sakhalin, b - Kunashir, c - Iturup, d - Shikotan which means that the frequency and intensity of tropical typhoon events in the territories of the Russian Far East with boreal forests will rise.

\section{CONCLUSIONS}

We verified that the global forest dynamics data set proves high correspondence to the actual windthrow distribution in Sakhalin forests and yet significantly underestimates disturbed patches area on the Kuril Islands. We believe our findings confirm that the windthrow distribution is primarily dependent on the direction and speed of wind. The visual assessment data leads us to the conclusion of higher windthrow vulnerability of dark conifer forests compared to mixed and birch forests. It appears that in the context of the increasing intensity of tropical cyclones in Northeast Asia, wind loads will become a serious forest ecosystem dynamics factor in the region, which will be reflected in the species composition and further direction of the successional changes. Taking into account the ongoing climate changes, the emerging windthrow patches may become ecosystem dynamics of the islands. It is typical for Sakhalin, the Kuril Islands, as well as the Japanese Hokkaido Island that spatial gaps created by disturbances are filled with wide-sweeping growth of dwarf bamboo species (Sasa spp.) (Tolmachev 1955, Popov 1969, Krestov et al. 2004, Altman et al. 2016). Dwarf bamboo thickets impede forest recovery and, therefore, disturbance events may lead to the decrease of the forested area on the islands in the nearest decade. However, the appearance of windthrow patches with disturbed soil cover (Ulanova 2000) creates potential regeneration niches for the warm to temperate tree species, such as Kalopnax septemlobus and Phellodendron sachalinense. Thus, in the context of climate warming, large-scale forest cover disturbances may act as triggers for overall ecosystem transformation of the southern boreal Sakhalin and the Kuril Islands zone.

Although it is not possible to predict with high accuracy the long-term effects of these ecosystem disturbances, it is clear that the large volume emergence of dead wood $\left(4.72 \cdot 10^{6}\right.$ tons) significantly increases the probability of catastrophic forest fires and the upsurge of wood destroying insects. Certain social changes have been noted as well. Windthrow debris made forests less passible to tourists and hunters which, in turn, reduced animal disturbances by humans. This has led to the increase of large mammal activity such as Sakhalin (Siberian) musk deer (Moschus moschiferus sachalinensis Flerov, 1929) near residential communities.

Disturbance events of this scale being more typical for temperate forests of Northeast Asia, were recorded for the first time in boreal conifer forests of the Russian Far East. There exists rather convincing data on the increase of tropical typhoon intensity (Webster et al. 2005, Mei Xie 2016, Klotzbach 2006, Wu et al. 2005), as well as the growing levels of wind-caused damages in the northern parts of Far Eastern forests (Altman et al. 2013, 2018). In all likelihood, this trend will continue into the future (Emanuel 2013) triggers of the boreal ecosystems' transition to the temperate type. The impact of wind should be considered in the management of forest systems.

\section{ACKNOWLEDGEMENTS}

The work was supported by the Russian Science Foundation (grant № 18-74-00007 to K.A. Korznikov). Authors are deeply grateful to Viktoria Chilcote and Mark Chilcote for the text translation.

\section{LITERAT URE CITED}

Altman, J., J. Dolezal, T.Cerný \& J.-S. Song 2013. Forest response to increasing typhoon activity on the Korean peninsula: Evidence from oak tree rings. Global Change Biology 19(2):498-504.

Altman, J., P. Fibich, J. Leps, S. Uemura, T. Hara \& J. Dolezal 2016. Linking spatiotemporal disturbance history with tree regeneration and diversity in an old-growth forest in northern Japan. Perspectives in Plant Ecology, Evolution and Systematics 21:1-13.

Altman, J., O.N. Ukhvatkina, A.M. Omelko, M. Macek, T. Plener, V. Pejcha, T. Cerny T., P. Petrik, M. Strutek, J.-S. Song, A.A. Zhmerenetsky, A.S. Vozmishcheva, P.V. Krestov, T.Y. Petrenko, K. Treydte \& J. Dolezal 2018. Poleward migration of the destructive effects of tropical cyclones during the 20th century. Proceedings of the National Academy of Sciences of the United States of America 115(45):11543-11548.

Angelstam, P. \& T. Kuuluvainen 2004. Boreal forest disturbance regimes, successional dynamics and landscape structures: a European perspective. Ecological Bulletins 51: 117-136.

Boose, E.R., D.R. Foster \& M. Fluet 1994. Hurricane impacts to tropical and temperate forest landscapes. Ecological Monographs 65(4):369-400.

Einzmann, K., M. Immitzer, S. Böck, O. Bauer, A. Schmitt \& C. Atzberger 2017. Windthrow detection in European forests with very high-resolution optical data. Forests 8(1):21. 
Emanuel, K.A. 2013. Downscaling CMIP5 climate models shows increased tropical cyclone activity over the 21st century. Proceedings of the National Academy of Sciences of the United States of America 110(30):12219-12224.

Everham, E.M. \& N.V.L. Brokaw 1996. Forest damage and recovery from catastrophic wind. Botanical Review 62(2): $113-185$

Fischer, A., P. Marshall \& A. Camp 2013. Disturbances in deciduous temperate forest ecosystems of the northern hemisphere: their effects on both recent and future forest development. Biodiversity Conservation 22(9):1863-1893.

Getzin, G., R.S. Nuske \& K. Kerstin 2014. Using unmanned aerial vehicles (UAV) to quantify spatial gap patterns in forests. Remote Sensing 6(8):6988-7004.

Guo, L.-P., L.-Z. Ji, W.-D. Zhang, Y. Zhang \& J.-G. Xue 2010. Forest recovery state in wind disaster area of Changbai Mountains, Northeast China. Chinese Journal of Applied Ecology 21(6):1381-1388 (in Chinese with English abstract).

Hansen, M.C., P.V. Potapov, R. Moore, M. Hancher, S.A. Turubanova, A. Tyukavina, D. Thau, S.V. Stehman, S.J. Goetz, T.R. Loveland, A. Kommareddy, A. Egorov, L. Chini, C.O. Justice \& J.R.G. Townshend 2013. High-resolution global maps of 21 st-century forest cover change Science 342(6160):850-853.

Hart, R.E. \& J.L. Evans 2001. A climatology of the extratropical transition of Atlantic tropical cyclones. Journal of Climate 14 (4):546-564.

Ishizuka, M., H. Toyooka, A. Osawa, H. Kushima, Y. Kanazawa \& A. Sato 1997. Secondary succession following catastrophic wind-throw in a boreal forest in Hokkaido, Japan: the timing of tree establishment. Journal of Sustainable Forestry 6(3-4):367-388.

Itô, H., T. Seki, I. Tsuyama \& S. Iida 2018. Long-term data on forest regeneration after catastrophic windthrow in Tomakomai, Hokkaido, northern Japan. Ecological Research 33(2):283.

Ivlev, A.M. 1965. Soils of Sakhalin, Nauka, Moscow, 116 pp. (in Russian). [Ивлев A.M. 1965. Почвы Сахалина. М.: Наука. 116 с.].

Jang, W.S. \& P.S. Park 2010. Stand structure and maintenance of Picea jezoensis in a northern temperate forest, South Korea. Journal of Plant Biology 53(3):180-189.

Klotzbach, P.J. 2006. Trends in global tropical cyclone activity over the past twenty years (1986-2005). Geophysical Research Letters 33(10):L10805.

Kramer, M.G., A.J. Hansen, M.L. Taper \& E.J. Kissinger 2001. Abiotic controls on long-term windthrow disturbance and temperate rain forest dynamics in Southeast Alaska. Ecology 82(10):2749-2768.

Krestov, P.V., V.Yu. Barkalov \& A.A. Taran 2004. Phytogeographic division of Sakhalin Island. In: Flora and Fauna of Sakhalin Island (Materials of International Sakbalin Project), part 1, pp. 67-90, Dal'nauka, Vladivostok (in Russian). [Крестов П.В., Баркалов В.Ю., Таран А.А. 2004. Ботанико-географическое районирование острова Сахалин // Растительный и животный мир острова Сахалин (Материалы Межлународного сахалинского проекта). ВАадивосток: Аальнаука. Часть 1. С. 67-90].

Kulakowski, D. \& T.T. Veblen 2002. Influences of fire history and topography on the pattern of a severe wind blowdown in a Colorado subalpine forest. Journal of Ecology 90(5):806-819.
McCarthy, J. 2001. Gap dynamics of forest trees: A review with particular attention to boreal forests. Environmental Reviews 9(1):1-59.

Mei, W. \& S.-P. Xie S-P 2016. Intensification of landfalling typhoons over the northwest Pacific since the late 1970s. Nature Geoscience 9:753-757.

Mitchell, S.J., T. Hailemariam \& Y. Kulis 2001. Empirical modeling of cutblock edge windthrow risk on Vancouver Island, Canada, using stand level information. Forest Ecology and Management 154(1-2):117-130.

Mitchell, S.J. 2013. Wind as a natural disturbance agent in forests: a synthesis. Forestry 86(2):147-157.

Mokroš, M., J. Výbošt'ok, J. Merganič, M. Hollaus, I. Barton, M. Koreň, J. Tomaštík \& J. Cerňava 2017. Early stage forest windthrow estimation based on unmanned aircraft system imagery. Forests 8(9):306.

Morimoto, J., M. Morimoto \& F. Nakamura 2011. Initial vegetation recovery following a blowdown of a conifer plantation in monsoonal East Asia: impacts of legacy retention, salvaging, site preparation, and weeding. Forest Ecology and Management 261(8):1353-1361.

Morimoto, J., K. Nakagawa, K.T. Takano, M. Aiba, M. Oguro, Ya. Furukawa, Yo. Mishima, K. Ogawa, R. Ito, T. Takemi, F. Nakamura \& C.J. Peterson 2019. Comparison of vulnerability to catastrophic wind between Abies plantation forests and natural mixed forests in northern Japan. Forestry; https://doi.org/10.1093/forestry/cpy045

Nakajima, T., J.-s. Lee, T. Kawaguchi, S. Tatsuhara \& N. Shiraishi 2009 . Risk assessment of wind disturbance in Japanese mountain forests. Écoscience 16(1):58-65.

Nakashizuka T. \& S. Iida 1996. Composition, dynamics and disturbance regime of temperate deciduous forests in Monsoon Asia. In: Global Change and Trrestrial Ecosystems in Monsoon Asia (T. Hirose, B. H. Walker, eds), pp. 23-30, Springer, Dordrecht.

NASA Jet Propulsion Laboratory (JPL), 2013, NASA Shuttle Radar Topography Mission global 3 arc second. Version $3.50^{\circ} \mathrm{N}, 140^{\circ} \mathrm{E}$. NASA EOSDIS Land Processes DAAC, USGS Earth Resources Observation and Science (EROS) Center, Sioux Falls, South Dakota; https://doi. org/10.5067/MEaSUREs/SRTM/SRTMGL3.003

Oliphant, T.E. 2007. Python for scientific computing. Computing in Science and Engineering 9:10-20.

Peel, M. C., B.L. Finlayson \& T.A. McMahon 2007. Updated world map of the Köppen-Geiger climate classification. Hydrology and Earth System Sciences 11:1633-1644.

Popov, M.G. 1969. Plant world of Sakhalin, Nauka, Moscow, 136 p. (in Russian). ППопов М.Г. 1969. Растительный мир Сахалина. М.: Наука. 136 с.].

Rich, R.L., L.E. Frelich \& P.B. Reich 2007. Wind-throw mortality in the southern boreal forest: effects of species, diameter and stand age. Journal of Ecology 95(6):1261-1273.

Seidl, R., P.M. Fernandes, T.F. Fonseca, F. Gillet, A.M. Jönsson, K. Merganičová, S. Netherer, A. Arpaci, J.-D. Bontemps, H. Bugmann, J.R. González-Olabarria, P. Lasch, C. Meredieu, F. Moreura, M.-J. Schelhaas \& F. Mohren 2011. Modelling natural disturbances in forest ecosystems: a review. Ecological Modelling 222(4):903-924.

Taylor, A.R., E. Dracup, D.A. MacLean, Y. Boulanger \& S. Endicott 2019. Forest structure more important than topography in determining windthrow during Hurricane Juan in Canada's Acadian Forest. Forest Ecology and Management 434:255-263. 
Tolmachev, A.I. 1955. Geobotanical division of Sakhalin Island, Izd-vo AN SSSR, Moscow, Leningrad, 80 p. (in Russian). [Толмачёв А.И. 1955 Геоботаническое районирование острова Сахалина. М.; А.: ИзА-во АН СССР. 80 с.].

Tsymek, A.A. \& K.P Solov'yev K.P. 1948. Forestry of Southern Sakhalin. Lesnoe khosyaistvo 1:81-84 (in Russian). [Цымек А.А., Соловьев К.П. 1948. Аесное хозяйство Южного Сахалина // Аесное хозяйство. № 1. С. 81-84].

Turton, S.M. \& M. Alamgir 2015. Ecological effects of strong winds on forests. In: Routledge Handbook of Forest Ecology, 1st edition (Peh K. S.-H., Corlett R.T., Bergeron Y., eds.), pp. 127-140, Routledge.

Ulanova, N.G. 2000. The effects of windthrow on forests at different spatial scales: a review. Forest Ecology and Management 135(1-3):155-167.

van der Walt, S., J.L. Schönberger, J. Nunez-Iglesias, F. Boulogne, J.D. Warnet, N. Yager, E. Gouillart \& T. Yu 2014. Scikit-image: image processing in Python. PeerJ; 2:e453
Webster, P.J., G.J. Holland, J.A. Curry \& H.-R. Chang 2005. Changes in tropical cyclone number, duration, and intensity in a warming environment. Science 309(5742): 1844-1846.

Wu, L., B. Wang \& S. Geng 2005. Growing typhoon influence on East Asia. Geophysical Research Letters 32(18): L18703.

Xi, W. 2015. Synergistic effects of tropical cyclones on forest ecosystems: a global synthesis. Journal of Forest Research 26(1): 1-21.

Xue, J.-G. \& Y.-X. Wu 2009. Investigation about vegetation restoration at typhoon ruined area in Jilin Changbai Mountain National Nature Reserve. Territory \& Natural Resources Study 1:95-96. (in Chinese with English abstract).

Yoshida, T., M. Noguch, S. Uemura, S. Yanaba, H. Miya \& T. Hiura 2011. Tree mortality in a natural mixed forest affected by stand fragmentation and by a strong typhoon in northern Japan. Journal of Forest Research 16(3):215-222. 